\title{
The Drosophila sex determination gene $s n f$ encodes a nuclear protein with sequence and functional similarity to the mammalian U1A snRNP protein
}

\author{
Thomas W. Flickinger and Helen K. Salz \\ Department of Genetics, Case Western Reserve University, Cleveland, Ohio 44106-4955 USA
}

\begin{abstract}
Alternative splicing controls the expression of many genes, including the Drosophila sex determination gene Sex-lethal. Previous studies have suggested that snf plays a role in regulating Sex-lethal splicing. Here, we demonstrate that $s n f$ is an integral component of the machinery required for splice site recognition. We have cloned snf and found that it has sequence homology to the mammalian U1A and U2B" snRNP proteins. Moreover, we establish that snf encodes a Drosophila protein shown previously to have functional similarity to U1A. Finally, with the isolation and analysis of a null mutation, we demonstrate that snf is an essential gene. These studies provide the first demonstration, in a multicellular organism, that mutations in a U1 snRNP protein alter splicing in vivo.
\end{abstract}

[Key Words: snf gene; Drosophila; sex determination; snRNP protein; pre-mRNA splicing]

Received January 24, 1994; revised version accepted March 4, 1994.

Control of RNA splicing has proven to be a common means of regulating differential gene expression (for review, see McKeown 1990; Green 1991). Although much is known about the biochemistry of the splicing reaction in vitro, the mechanisms regulating alternative splice site choices remain largely speculative. To further our understanding of the mechanisms of splicing regulation, we have chosen to use the Drosophila sex determination system because of its accessibility to genetic techniques (for review, see Belote 1992; Burtis and Wolfner 1992; McKeown and Madigan 1992; Steinmann-Zwicky 1992; Cline 1993; Cronmiller and Salz 1994|. By focusing on the identification of mutations that disrupt specific alternative splicing events, we hope to identify products that play a crucial role in splicing regulation irrespective of whether they are structural or regulatory components of the splicing machinery. In particular, our approach has been to identify and characterize mutations that disrupt the sex-specific splicing pattern of Sex-lethal (Sxl).

$\mathrm{Sxl}$ is a binary switch gene that regulates the three major aspects of sexual cell fate: somatic sexual differentiation, germ-line development, and X-chromosome dosage compensation (for review, see Cline 1993; Cronmiller and Salz 1994). If $S x l$ is "on", the female developmental pathway is selected; alternatively, if $S x l$ is "off", male development ensues. Because of its role in the vital process of dosage compensation, loss-of-function mutations result in female-specific lethality and gain-of-function mutations result in male-specific lethality. Although the on/off regulation of $S x l$ is controlled prima- rily at the level of RNA splicing, female-specific expression is initially regulated at the level of transcription (Keyes et al. 1992). Once female-specific expression is initiated, a switch from the female-specific promoter to the nonsex-specific-promoter results in the production of nonsex-specific pre-mRNAs (Salz et al. 1989; Keyes et al. 1992). These pre-mRNAs are differentially spliced such that only the female-specific mRNA contains a large open reading frame (ORF) (Bell et al. 1988; Samuels et al. 1991). One of the first splicing factors to be identified as necessary for the on/off regulation of $S \times l$ was Sxl itself (Cline 1984; Bell et al. 1991; Keyes et al. 1992). $S x l$ is believed to control its own splicing by the SXL protein binding its own pre-mRNA to block recognition of the male-specific exon (Sakamoto et al. 1992; Horabin and Schedl 1993a,b|. In addition to $S x l$ itself, genetic studies have identified two other genes that regulate Sxl splicing: fl(2)d (Granadino et al. 1990, 1991, 1992) and snf (Oliver et al. 1988; Steinmann-Zwicky 1988; Salz 1992; Albrecht and Salz 1993; Bopp et al. 1993; Oliver et al. 1993). Although genetic studies have suggested that $f l(2) d$ is required throughout development to maintain the female-specific splicing pattern of $S x l$, no molecular data are available to elucidate further its role in splicing regulation.

In this paper we investigate the molecular mechanism by which snf regulates the sex-specific splicing of $S x l$. snf was first identified as a positive regulator of $S x l$ in the germ line based on the analysis of a single allele, $s n f^{1621}$ (Oliver et al. 1988, 1993; Steinmann-Zwicky 1988; Salz 
1992; Bopp 1993). Females homozygous for this allele are sterile because the germ-line components of the ovary form ovarian tumors that express $S x l$ in the male-specific mode (Bopp et al. 1993; Oliver et al. 1993). In contrast to its role in germ-line sex determination, the role of the snf gene in somatic sex determination can only be inferred from a female-lethal synergistic interaction between snf and $S x l$ (Oliver et al. 1988; Steinmann-Zwicky 1988; Salz 1992). Analysis of this female-lethal interaction has suggested that $s n f$ is utilized to establish the female-specific splicing pattern of the Sxl mRNA (Albrecht and Salz 1993).

Here, we demonstrate that $s n f$ is a U1 snRNP protein and is therefore an integral component of the machinery required for splice site recognition. We have cloned the snf gene and found that it encodes a nuclear protein with homology to the mammalian U1A and U2B" small nuclear ribonucleoprotein particle (snRNP) proteins. Moreover, we have established that snf encodes a Drosophila protein shown previously to have functional similarity to the U1 snRNP-specific U1A protein. Finally, with the isolation and analysis of a null mutation, we show that snf function is not limited to sex determination: A complete loss of snf function results in embryonic lethality. Taken together, these results strongly suggest that snf plays a direct role in alternative splice site selection. Although biochemical studies will be required to establish the exact role of snf in splicing, the data presented here underscore the importance of snRNP proteins in regulating alternative splicing events in vivo.

\section{Results}

\section{Identification of the snf genomic region}

As the first step toward cloning the snf gene, we screened for P-element insertions that failed to complement snf ${ }^{1621}$. Because $\mathrm{P}$ elements are thought to transpose preferentially into genomic regions close to their original insertion sites (Tower et al. 1993), we mobilized a $\mathrm{P}[$ lacW $]$ element, located in 4F1,2, within the coding sequence of the closely linked deadhead (dhd) gene (Salz et al. 1994). Although females homozygous for this P-element insertion, designated $d h d^{P 8}$, are female-sterile, $d h d^{P 8}$ fully complements $s n f^{1621}$ and is therefore not allelic to snf.

Of $\sim 700$ male-viable derivative lines established after mobilization of the P-element insertion in $d h d^{P 8}$, one new P-element insertion, $s n f^{P R 110}$, failed to complement both $s n f^{1621}$ and $d h d^{P 8}$. Excision of the $P$ element within $s n f^{P R 110}$ did not revert either the snf or the dhd mutant phenotypes, suggesting that $s n f^{P R 110}$ had both a P-element insertion and an additional chromosomal rearrangement. Cloning of the genomic DNA flanking the P-element insertion site in $s n f^{P R 110}$ revealed that $s n f^{P R 110}$ contained both a P-element insertion and a deletion of $\sim 3-\mathrm{kb}$ of genomic DNA on the $5^{\prime}$ side of $d h d$ (Fig. 1). Another P element-derived deletion, snf $f^{I A 2}$, was characterized at the molecular level and found to be identical to $s n f^{P R 110}$; however, the P element had excised from $s n f^{I A 2}$ (Fig. 1). These data located the sequences required for $s n f$ function to within $\sim 3 \mathrm{~kb}$ of $d h d$.

\section{The snf gene encodes a $1.0-\mathrm{k} b$ non-sex-specific transcript}

Genomic DNA fragments from the region 5' of $d$ hd were used as probes on Northern blots to identify a single $1-\mathrm{kb}$ non-sex-specific RNA adjacent to $d h d$ (Salz et al. 1994 and data not shown). The possibility that snf encodes a non-sex-specific transcript is consistent with our understanding of snf function, as genetic studies had shown that snf mutations can affect $S x l$ expression in both

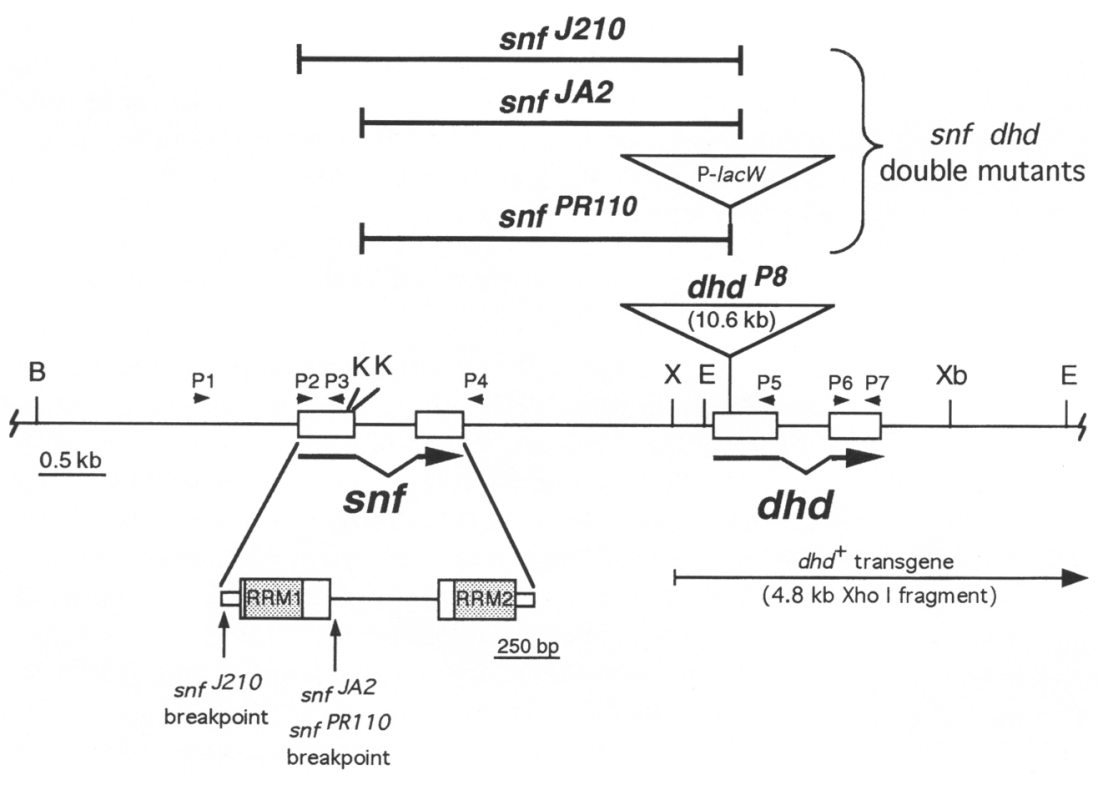

Figure 1. Molecular map of the region surrounding snf. The extent of the deletions in the region and the position of inserted $\mathrm{P}$ elements are indicated at the top of the diagram by heavy lines and inverted triangles, respectively. $s n f^{P R 110}$ was identified in a screen to mobilized the $\mathrm{P}$ element within $d h d^{P 8}$ (see Materials and methods). $s n f^{I A 2}$ and $s n f^{I 210}$ are derivatives of $s n f^{P R 110}$ (see Materials and methods). ( $\square$ ) Exons; (thin lines) intervening sequences. Restriction enzyme sites are indicated by (B) BamHI, (E) EcoRI, (K) KpnI, (Xb) $X b a \mathrm{I}$, and $(\mathrm{X})$ XhoI. Arrows labeled P1-P7 show the location and orientation of primers used for PCR amplification. The location of the $4.8-\mathrm{kb}$ Xhol fragment that rescues $d h d$ mutations is indicated (lower right). In the expanded view of the snf locus (lower left), the small open boxes represent untranslated regions. 
males and females (Steinmann-Zwicky 1988; Salz 1992). To determine whether this RNA corresponds to snf, several corresponding cDNAs were isolated from a head cDNA library (Itoh et al. 1986); one of these cDNAs, $\lambda K E-14$, was characterized further. When used as a probe on Northern blots, $\lambda \mathrm{KE}-14$ detected a 1-kb non-sex-specific RNA that is missing in homozygous $s n f^{P R 110}$ and $s n f^{I A 2}$ animals but not in $d h d^{P 8}$ animals (Fig. 2). Instead, a 0.9-kb RNA was detected in both $s n f^{I A 2}$ and $s n f^{P R 110}$ animals but not in $d h d^{P 8}$ animals. Southern blot and RNase protection analysis demonstrate that the deletions associated with $s n f^{P R 110}$ and $s n f^{I A 2}$ remove the second exon of this transcriptional unit and break within the intron (Figs. 1 and 3). Thus, it is likely that the $0.9-\mathrm{kb}$ transcript produced by these deletion alleles is a truncation of the wild-type message. This finding, in conjunction with the finding that $\operatorname{sn} f^{1621}$ is a missense mutation within the coding region of this 1-kb RNA (see below), identifies this mRNA as a transcript of the snf gene.

snf encodes a RRM protein with homology to two similar snRNP proteins: $U 1 A$ and $U 2 B^{\prime \prime}$

The insert within the $\lambda \mathrm{KE}-14 \mathrm{cDNA}$, as well as the corresponding genomic region, was sequenced and found to have an ORF of 216 amino acids that would produce a protein with an apparent molecular mass of $28 \mathrm{kD}$ (Fig. 3 ). The predicted protein contains two RNA recognition motifs (RRMs), one at the amino terminus and the other at the carboxyl terminus (for review, see Kenan et al. 1991). This protein shows extensive overall similarity to two closely related human snRNP proteins, UlA and

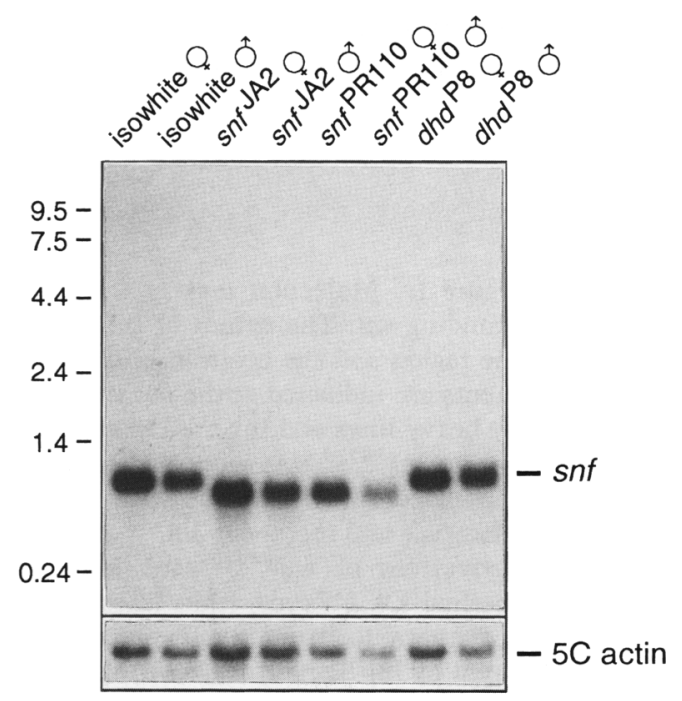

Figure 2. Identification of the snf transcriptional unit. Northern transfer of 5- $\mu$ g samples of poly $(\mathrm{A})^{+}$RNA prepared from sexed adults from wild-type, snf $f^{I A 2}, \operatorname{snf} f^{P R 110}$, and $d h d^{P 8}$ homozygous flies probed with the snf cDNA. To control for the amount of RNA loaded onto each lane, the blot was subsequently reprobed with $5 \mathrm{C}$ actin DNA (Fryberg et al. 1983). The positions of the RNA size standards are indicated at left.
U2B" (Habets et al. 1987; Sillekens et al. 1987). U1A and U2B" are two highly similar RNA-binding proteins that bind different target RNAs. U1A binds U1 snRNA, and U2B" binds U2 snRNA. Between SNF and these two human proteins, the amino acid identity is $72 \%$ and $70 \%$, respectively (Fig. 4). For just the amino terminal RRM domain, which is responsible for the snRNA-binding specificity of UlA and U2B'", the identity is even stronger: $82.5 \%$ with U1A and $79 \%$ with U2B" (Scherly et al. 1990a,b; Bentley and Keene 1991; Jessen et al. 1991; Kenan et al. 1991; Tsai et al. 1991). Finally, the amino-terminal RRM domain of the SNF protein also shows extensive homology to U1A in Xenopus $169 \%$ identity), to $U 2 B^{\prime \prime}$ in potato (54\% identity), but not to U1A in yeast ( $14.5 \%$ identity) (Kenan et al. 1991; Scherly et al. 1991; Simpson et al. 1991; Liao et al. 1993). Interestingly, even though the function of the carboxy-terminal RRM is not known, it too is highly conserved between Drosophila, human, Xenopus, and potato (Fig. 4B).

We also found that the SNF protein is identical to a previously cloned Drosophila gene, D25, reported to have functional similarity to U1A (Harper et al. 1992). Although Harper et al. (1992) did not publish a cytological location for $D 25, D 25$ must be snf because the sequences of the cDNAs are virtually identical. We found only five differences between the sequence of the snf cDNA and that published by Harper et al. (1992); none of these differences results in any change in the coding potential (Fig. 3).

snf ${ }^{1621}$ contains a single point mutation within the amino-terminal $R R M$

To establish further that we have cloned the snf gene, we characterized the molecular lesion associated with $s n f^{1621}$ by amplifying and sequencing the genomic DNA from this mutant allele and its parent chromosome. The $s n f^{1621}$ mutation resulted from a $\mathrm{G}$ to $\mathrm{A}$ transition /at position 209 , Fig. 31, substituting a histidine for an arginine residue in the amino terminal RRM (at position 49, Fig. 4B). As illustrated in Figure 4B, this arginine is conserved in both U1A and U2B" proteins. Moreover, in vitro structure/function studies have shown that this residue is crucial for human U1A to bind its target RNA (Nagai et al. 1990; Jessen et al. 1991).

\section{SNF is a nuclear protein recognized by an antibody specific for mammalian $U 2 B^{\prime \prime}$}

Previously, a monoclonal antibody (mAb 4G3) directed against the human U2B" was shown to detect a Drosophila nuclear antigen that is similar in size to the predicted 28-kD SNF protein (Habets et al. 1989; Amero et al. 1992; Bopp et al. 1993). Is this antigen SNF? The epitope for mAb 4G3 has been mapped to the carboxyterminal RRM of U2B" (Habets et al. 1989). Thus, if $\mathrm{mAb} 4 \mathrm{G} 3$ was specific for SNF, then the $28-\mathrm{kD}$ protein would not be detected in extracts from either $s n f^{I A 2}$ or $s n f^{P R 110}$ flies because both of these alleles carry deletions that remove the second exon of the gene, including 


\begin{abstract}
tgccatcgct gttgaccagc aattgttgg gcttcaaatc gcggtgcagt atccaatga gatgcaata ctccagaccc -835 tttagcgtca tgatggcata ggccttgatg ttcgcctgcg ttaatataat cttgttatcc ttgatgatca cctccagatc -755 cgtgtccatg aagtcgaaaa ccagcgagac attcgaaagt tgaccgaaaa cgtccaccaa gccaatgata ttctcgtgct -675 gcagctcctg caatatcttg atctcacgca gcgctgtcct gttgataccg tcgcgtgcat cctcgcgcga tcccttcttg - 595 atcttctta cggccacaat ttggttggtc accgtgtcgc gcgccttgta aactgtggca aactgcggtg cgaaagtgga -515 atgcgcacat tgttatggat cgttgggttg atatccgtgg cggcggactc acctgaccct cgccgaggaa ggatagcttg -435 gcatagcgtt ccgttttgtc attcgcattg ggcagcatcg tttaggagcc tcataatag cacgaaatg actgaaatgc - 355 tgcgaggccg aatcaaaaca attcaagttc gcaaacgcta tcgatggccg ataaccgatg gacgccggta gggcctatcg -275 cgcgccccaa aaaaatact agatttcaga gtctattaag aataatgcaa aaacagcgta ttgctccttt attgctaatc -195 aattttatag tttaacaagt tatgcaata atacacaact gtcaattta attagctgca tgtgattgtc atttaattt agctacttt agctatgtgc agtttaacaa cactgccaaa caccggtgcg ataacatatc gatagaccgc cccaaacgat - 35 $1 \quad \downarrow-s n f^{J 210}$ breakpoint
\end{abstract}

gccttctget atcgatgaca gactcgtttt ttttCTCAAC AATACAGAGC AAATTGGTTG ATTTTTGTCG AATTAAGTGA 46

ATAAAACGCA CGACAgG ATG GAG ATG CTA CCC AAC CAA ACG ATT TAC ATC AAC AAT CTG AAC GAG AAG 114

ATC AAg AAg GAg GAg CTA AAG AAg TCG CTC TAT GCG ATT TTC TCG CAA TTC GGC CAA ATT CTG GAC

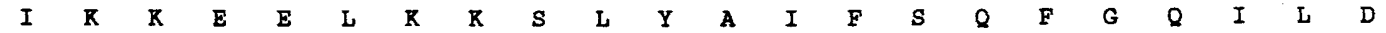
$A-\operatorname{snf} 1621$

ATT GTG GCC CTA AAA ACG CTC AAA ATG CGC GGC CAG GCA TTT GTG ATC TTC AAG GAG ATC GGC AGC

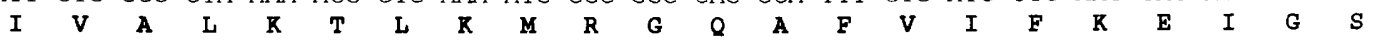

GCT TCG AAT GCC CTG CGC ACC ATG CAG GGC TTC CCG TTC TAC GAC AAG CCC ATG CAG ATC GCC TAC

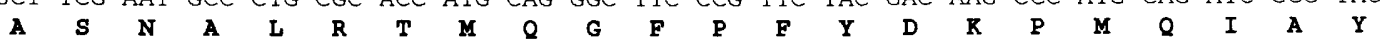
TCC AAA TCC GAT TCG GAT ATT GTG GCC AAG ATA AAG GGT ACC TTC AAG GAG CGC CCC AAG AAG GTC $\begin{array}{llllllllllllllllllllllll}\mathbf{S} & \mathrm{K} & \mathbf{S} & \mathrm{D} & \mathbf{S} & \mathrm{D} & \mathrm{I} & \mathrm{V} & \mathrm{A} & \mathrm{K} & \mathrm{I} & \mathrm{K} & \mathrm{G} & \mathrm{T} & \mathrm{F} & \mathrm{K} & \mathrm{E} & \mathrm{R} & \mathrm{P} & \mathrm{K} & \mathrm{K} & \mathrm{V}\end{array}$

AAG CCA CCA AAA CCA GCG CCG GGT ACC GAT GAG AAG AA gtgagtatcC caattgctaa ttgggcccgt

ttagattcaa tcatttgttg ccaacggcca tggtgctacc atttgttgct ccctgttgcc tcgcaaaaac ccaatgttt cattcgcacg cctgaaatcc ttttgctac taaaacatt tccgcattaa ccaatgttag ttttggcca gaattatgga cttgaaaacc aagaggtgtc tcaagtcttc ataatatctt tagttatcaa ctccttttg ctcttaatc gatgcgattt gagttccagt tgcaaalgt ttcattttg ttcattttg cgcgacaaa atccgtagta atcctagttt tctgggatgt

gcgaatgact aggcaaaaaa aaatgcaac ttcatgtgac actaagacaa ctccttttt tttcgttcg cacag $G$ GAC 845 G-RE14

AAG AAG AAG AAG CCG AGC AGC GCC GAG AAC TCG AAC CCG AAC GCA CAG ACC GAA CAG CCG CCG AAC

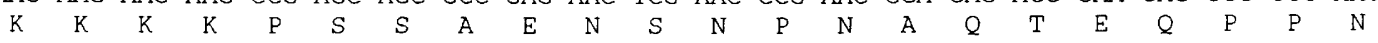
CAG ATC CTC TTC CTC ACC AAT CTG CCC GAG GAG ACC AAC GAG ATG ATG CTG TCC ATG CTG TTC AAT

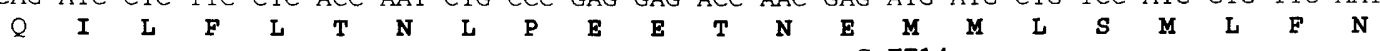
CAG TTC CCC GGC TTC AAG GAG GTG CGT CTT GTG CCG AAT CGT CAC GAC ATC GCC TTT GTG GAG TTC 1043

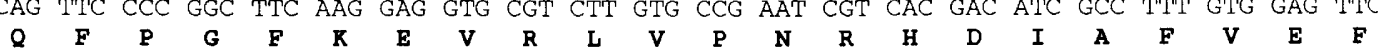
ACC ACC GAG TTG CAG AGC AAT GCC GCC AAG GAG GCG CTG CAG GGC TTC AAG ATT ACG CCG ACG CAC 1109 $\begin{array}{llllllllllllllllllllll}\mathbf{T} & \mathbf{T} & \mathbf{E} & \mathbf{L} & \mathbf{Q} & \mathbf{S} & \mathbf{N} & \mathbf{A} & \mathbf{A} & \mathbf{K} & \mathbf{E} & \mathbf{A} & \mathbf{L} & \mathbf{Q} & \mathbf{G} & \mathbf{F} & \mathbf{K} & \mathbf{I} & \mathbf{T} & \mathbf{P} & \mathbf{T} & \mathbf{H}\end{array}$ GCC ATG AAG ATA ACG TTC GCC AAG AAG TGA ACGCAACT CCAGTCGCCG GgCGTTCCAG CAACTCCAAT

\title{
$\begin{array}{lllllllllll}\mathbf{A} & \mathbf{M} & \mathbf{K} & \mathbf{I} & \mathbf{T} & \mathbf{F} & \mathbf{A} & \mathbf{K} & \mathbf{K} & *\end{array}$
}

AATAATTTAA ACTATAGAAT AAATCGATAT AAACAAAcaa actacgagta ttccatatgc ccatatccct cccatatcCC 1257 gatttcgccC aaagagtcct taaaggctaa aagtatagaa tagaatagtt tattgttatt gtgtagatct a

Figure 3. Nucleotide and deduced amino acid sequence of the snf genomic locus. The genomic nucleotide sequence corresponding to the snf cDNA is indicated by uppercase letters; the flanking and intervening nucleotide sequences are in lowercase. The putative translation product in the single-letter amino acid code with the RRM domains in bold is presented below the nucleotide sequence. The polyadenylation signal is underlined, and the polyadenylation site is marked by a double-shafted arrow. The exact location of the $s n f^{210}$ breakpoint is indicated by an arrow, and the location of the snf ${ }^{1621}$ missense mutation is shown. In addition, the approximate location of the $s n f^{P R 110}$ and $s n f^{I A 2}$ mutations are indicated $(\downarrow)$. There are no nucleotide differences between the D25 cDNA (Harper et al. 1992; GeneBank accession number M89775 / and the corresponding regions of this genomic sequence. On the other hand, the snf cDNA that we isolated, $\lambda \mathrm{KE}-14$, has 5 nucleotide differences from this sequence that do not result in an alteration of coding potential. Three of these differences are illustrated; however, a dinucleotide insertion (GA; after nucleotide 37) present in the snf cDNA of $\lambda \mathrm{KE}-14$ is not shown. The genomic sequence reported here has been assigned GenBank accession number L29521.

the carboxy-terminal RRM (see Fig. 1). As illustrated in Figure $5 \mathrm{~A}, \mathrm{mAb} 4 \mathrm{G} 3$ recognizes a $28-\mathrm{kD}$ protein in wildtype animals but not in either $\operatorname{sn} f^{I A 2}$ or $\operatorname{sn} f^{P R 110}$ animals.
Similarly, no cross-reacting antigen was detected in whole-mount immunohistochemical staining of tissues from snf ${ }^{I A 2}$ homozygous animals (Fig. 6C,E). The failure 


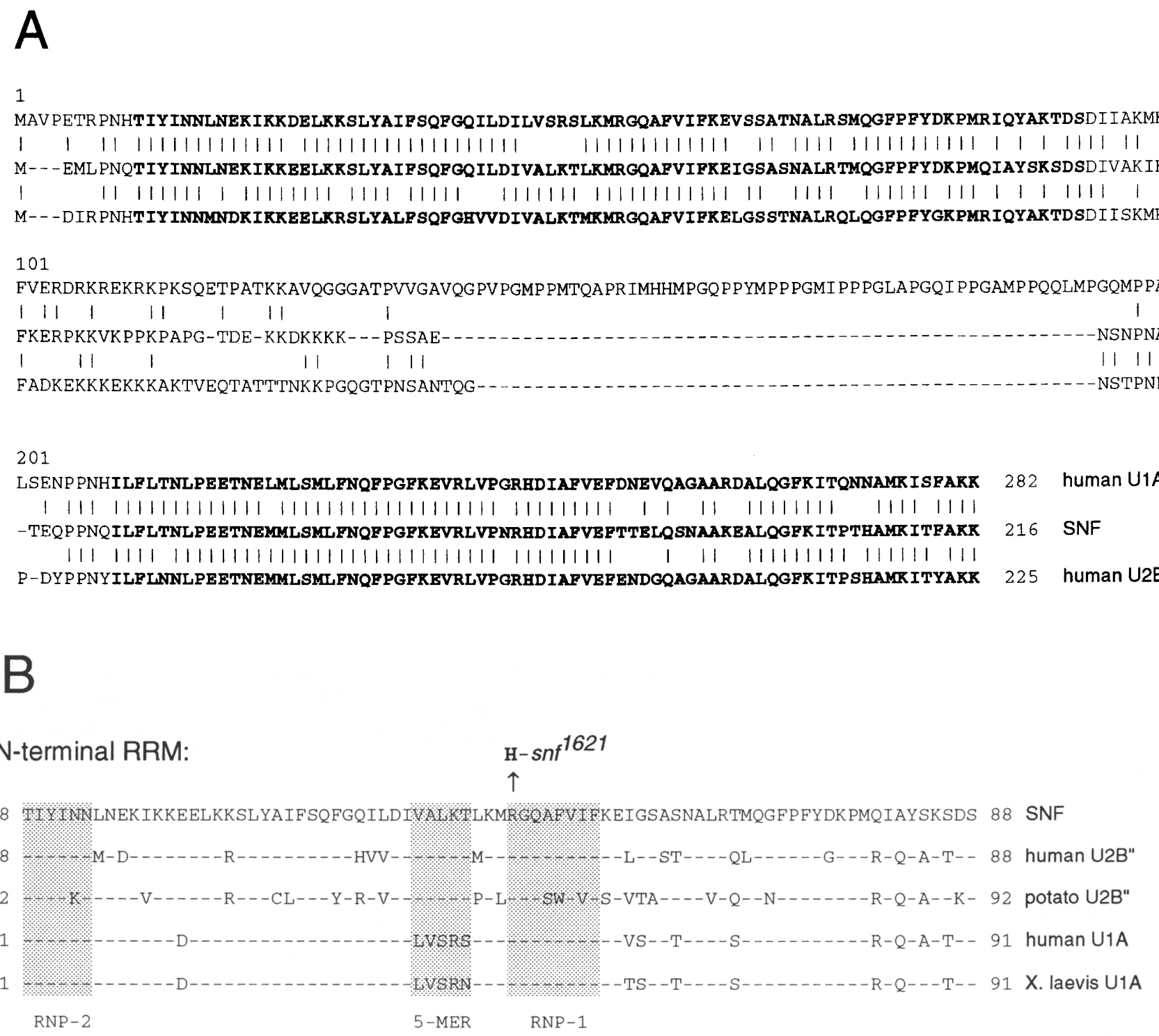

\section{C-terminal RRM:}

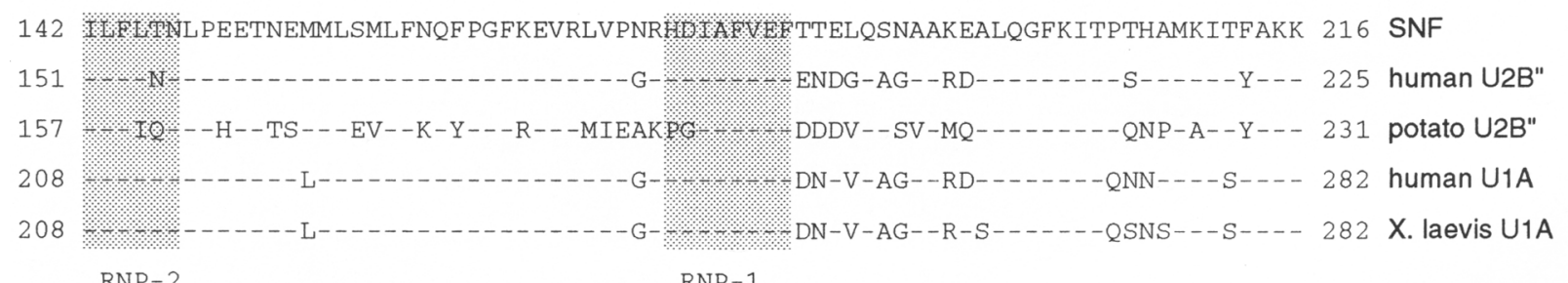

RNP-2

RNP-1

Figure 4. snf encodes a protein with homology to the U1A and U2B" snRNP proteins. (A) Comparison of the 28-kD snf translation product with the human U1A and U2B" snRNP proteins. The predicted SNF protein contains two RMM motifs, one at the amino terminus and one at the carboxyl terminus. Amino acid identities are denoted by vertical lines; the lack of a corresponding residue is represented by dashes. Amino acids are identified by their single-letter code and the RRMs (as defined by Kenan et al. 1991) are in boldface type. $(B)$ A detailed comparison of the amino acid sequences for the amino-terminal and carboxy-terminal RRMs of SNF with the human U2B" and U1A proteins, the potato U2B" protein, and the Xenopus U1A protein (Habets et al. 1987; Sillekens et al. 1987; Scherly et al. 1991; Simpson et al. 1991). Also indicated are the different components of the RRM: RNP-1, RNP-2, and 5-MER. [For a complete description of these motifs, see Kenan et al. (1991).] The amino acids are identified by their single-letter code and identical amino acids are represented by a dash. 


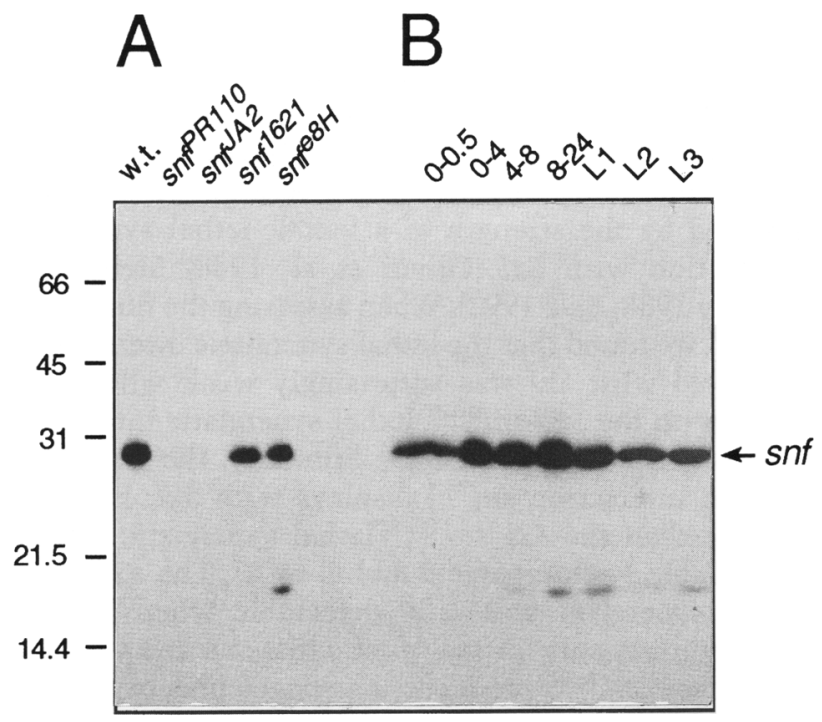

Figure 5. The SNF protein is recognized by an antibody directed against the mammalian U2B" throughout development. (A) Western transfer of protein extracts from homozygous adult wild-type, $s n f^{I A 2}, s n f^{P R 110}, s n f^{e 8 H}$, and $s n f^{1621}$ females probed with mAb 4G3. $(B)$ Developmental profile of the SNF protein. Proteins were extracted from wild-type adults and staged embryos and larvae. The ages of the embryos are in hours after egg deposition $\left(25^{\circ} \mathrm{C}\right)$. The Western blot contains equal amounts of protein in all lanes except for the 0- to 30-min embryo collection, which contained about half the amount of protein /data not shown). The locations of protein size standards (Bio-Rad) (in $\mathrm{kD}$ ) are indicated at left.

to detect a protein in the $3^{\prime}$ deletion mutations establishes that mAb $4 \mathrm{G} 3$ is specific for SNF protein.

To determine the temporal distribution of the SNF protein, we probed Western blots containing protein extracts from different stages of development with $\mathrm{mAb}$ 4G3 and found the protein present in all stages examined (Fig. 5B). To examine more precisely the subcellular localization of SNF, mAb 4G3 was used to stain wholemount embryos and larval tissues. We found that $\mathrm{mAb}$ 4G3 staining is localized to the nucleus in all tissues throughout most of development /Fig. 6B,D; data not shown). For example, we found staining localized to the polytene nuclei of salivary glands from third-instar larvae (Fig. $6 \mathrm{D}$ ). These results are consistent with those obtained previously by Amero et al. (1992) who found that $\mathrm{mAb} 4 \mathrm{G} 3$ detected an antigen that is associated with many sites throughout the polytene chromosomes. As might be expected, we found that the staining of chromosomes is not limited to the salivary gland. During the early embryonic mitotic divisions, we also observed staining to condensed chromosomes (data not shown). Together with the developmental Western analysis, these data clearly demonstrate that SNF is a nuclear protein that is expressed throughout development.

Because genetic data have demonstrated a requirement for maternal snf function, we examined the expression of SNF in early embryos and during oogenesis. When West- ern blots containing protein extracts from newly laid eggs (0-30 min of development) were probed with $\mathrm{mAb}$ $4 \mathrm{G} 3$, we found that the $28-\mathrm{kD}$ SNF protein was present (Fig. 5B). In contrast to most of development, wholemount antibody staining of these early embryos revealed that SNF was non-nuclear; mAb 4G3 staining was homogeneously distributed throughout these syncytial embryos (Fig. 6A). Several mitotic divisions later, SNF was restricted to the nuclei (Fig. 6B; data not shown). To determine whether SNF is likely to be among the proteins made by the nurse cells and deposited into the oocyte, we examined the distribution of mAb 4G3 antigens in the ovary. All nuclei in both the germ-line and the somatic components of the ovary were found to be stained by mAb 4G3. Furthermore, we found high levels of staining in the cytoplasm of the nurse cells, suggesting that the SNF protein is deposited into the developing
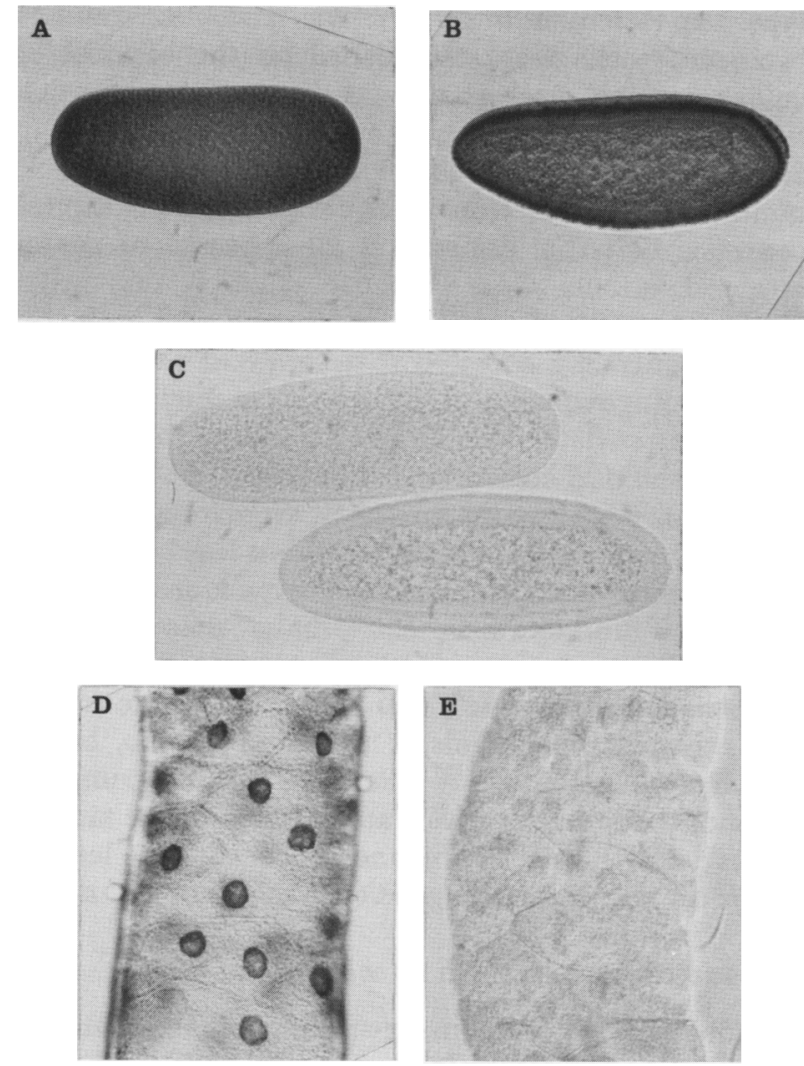

Figure 6. The SNF protein is nuclear throughout most of development. Whole-mount immunostaining of wild-type and homozygous snf $f^{I A 2}$ embryos and salivary glands with mAb 4G3. $s n f^{I A 2}$ embryos and larvae were collected from a $s n f^{I A 2} / s n f^{I A 2}$; $P\left(w^{+}, d h d^{+}\right) / P\left(w^{+}, d h d^{+}\right)$stock. $(A)$ The protein is distributed uniformly in a preblastoderm wild-type embryo. $(B)$ The protein is nuclear in all cell types in a wild-type cellular blastodermstage embryo. $(C)$ No protein is detected in homozygous snf ${ }^{I A 2}$ embryos preblastoderm (top) or cellular blastoderm embryos. $(D)$ The protein is nuclear in a salivary gland from a wild-type third-instar larva. $(E)$ No protein is detected in salivary glands from a homozygous $s n f^{I A 2}$ third-instar larva. 
oocyte when the nurse cells dump their contents /data not shown).

\section{The null phenotype of snf is a non-sex-specific lethal}

Although previous genetic studies have shown that mutations in snf disrupt the establishment of the $S x l$ female-specific splicing pattern in both the germ line and the soma (Albrecht and Salz 1993; Bopp et al. 1993; Oliver et al. 1993), the most extreme allele isolated until now, $s n f^{1621}$, is associated only with female sterility, suggesting that snf may only be essential in the female germ line (Gans et al. 1975; Salz 1992). However, based on genetic criteria, this allele appears to retain some function (Gollin and King 1981). Similarly, the $3^{\prime}$ deletion mutant allele, $s n f^{I A 2}$, is not a candidate for a null allele because it retains significant amounts of snf gene activity (see below).

To determine unequivocally the null phenotype, we screened directly for deletions of the entire snf-coding sequence in a manner that was independent of phenotype. The P element in $s n f^{P R 110}$ was remobilized and 347 balanced stocks were established on the basis of eye color reversion. Each stock was then screened for deletions of the first snf exon by a combination of PCR and Southern analysis. Of 335 homozygous viable stocks, none contained deletions of the remaining snf exon. In contrast, 12 lethal derivatives all appeared to contain larger deletions. One of these deletion derivatives, $s n f^{\prime 210}$, appeared to contain a breakpoint within the first exon. Sequencing revealed that $s n f^{J 210}$ does delete the entire coding sequence of $s n f$, starting at nucleotide 21 of the 5 '-untranslated region and extending into, but not beyond, the $d h d$-coding sequence (Figs. 1,3).

Animals homozygous for $s n f^{J 210}$ were found to be embryonic lethals (data not shown). Two lines of evidence demonstrated that the lethal phenotype is attributable to lack of snf function. First, the lethality mapped by both recombination and deficiency mapping to the same interval as the snf locus. Within this region there are only two other known lethals, $1(1) 4 F a$ and $1(1) 4 F b$, both of which complement $s n f^{j 210}$ (Salz 1992; H. Salz, unpubl.). Second, the lethality is not attributable to the simultaneous deletion of both $d h d$ and snf because the lethality is not rescued by a transgene carrying a copy of $d h d^{+}$.

\section{Genetic characterization of the new snf alleles}

Although $s n f^{1210}$ is a non-sex-specific lethal, its function in germ-line sex determination is still evident when one examines the ovaries of viable combinations of snf mutations. For instance, $s n f^{I 210} / s n f^{I A 2}$ (in the presence of a transgene carrying a copy of $d h d^{+}$; see Fig. 1) and $s n f^{1210} / s n f^{1621}$ females produced ovarian tumors.

Surprisingly, and in contrast to either $s n f^{1210} / s n f^{I A 2}$ females or $s n f^{1621}$ homozygous females, females homozygous for snf $f^{I A 2}$ are fertile (in the presence of a transgene carrying a copy of $d h d^{+}$; see Fig. 1). The observation that the $s n f^{I A 2}$ deletion mutation is homozygous viable suggests that the carboxyl terminus of the protein is not essential for function. In vitro structure/function analysis of the mammalian U1A protein have shown previously that a fragment containing only the amino-terminal RRM binds U1 snRNA with the same affinity as the native protein (Jessen et al. 1991; Tsai et al. 1991).

The role of snf in somatic sex determination can be assessed by the strength of a female-lethal synergistic interaction with Sxl (Oliver et al. 1988; SteinmannZwicky 1988; Salz 1992). When assessing the function of $s n f^{I 210}$, we found that the lethal synergistic interaction it displayed with $S x l$ was surprisingly weak when compared with the $S x l-s n f^{1621}$ lethal synergistic interaction (Table 1 ; cf. crosses A and D). Similarly, the lethal synergistic interaction $s n f^{I A 2}$ displays with $S x l$, is clearly weaker than the $S x l-s n f^{1621}$ lethal synergistic interaction (Table 1; cf. crosses B and C to A). The Sxl-snf $f^{I A 2}$ lethal synergism was only detectable when mothers were homozygous for snf $f^{I A 2}$ (cf. crosses B and C).

Because $s n f^{1621}$ produces a stronger phenotype than loss-of-function mutations, it can be classified as a gainof-function mutation. Gain-of-function mutations, like $s n f^{1621}$, whose mutant phenotypes are suppressed by an extra copy of the wild-type gene, are thought to disrupt the processes in which they normally participate (Salz 1992; Albrecht and Salz 1993; H. Salz, unpubl.). The similarity in phenotype between $s n f^{1621}$ and the viable lossof-function mutations further suggests that complexes containing the the $\mathrm{SNF}^{1621}$ protein interfere with the establishment of the $S_{x l}$ autoregulatory loop by functional inactivation of U1 snRNPs. Taken together, these results demonstrate that $s n f^{1621}$ is an antimorphic or dominant-negative mutation (Muller 1932; Herskowitz 1987).

\section{Discussion}

In Drosophila, the choice between male and female development requires that $S x 1$ activity be tightly controlled throughout development. In females, Sxl maintains its activity state by an autoregulatory feedback loop in which SXL protein directs the female-specific splicing pattern of its own pre-mRNA (Cline 1984; Bell et al. 1991; Keyes et al. 1992; Sakamoto et al. 1992; Horabin and Schedl 1993a,b). Although previous studies had shown that snf also participates in the establishment of the $S x l$ autoregulatory loop, it remained to be determined whether snf was directly involved in female-specific splicing (Albrecht and Salz 1993; Bopp et al. 1993; Oliver et al. 1993). Our finding that the SNF protein is localized to the nucleus and has extensive homology to biochemically characterized RNA-binding proteins strongly suggests that SNF directly influences splicing regulation. Furthermore, by characterizing an unambiguous snf null mutation, we show that the function of snf is not limited to sex determination: A complete loss of snf function results in embryonic lethality.

snf encodes a U1 snRNP protein

We show here that snf encodes a nuclear protein with strong homology to two highly similar snRNP proteins, 
The sex determination gene snf is a snRNP protein

Table 1. Female-lethal synergism between snf and $\mathrm{Sxl}$

\begin{tabular}{|c|c|c|c|c|c|}
\hline \multirow[b]{2}{*}{ Cross $^{1}$} & \multirow[b]{2}{*}{$\begin{array}{l}\text { Maternal } \\
\text { genotype }\end{array}$} & \multicolumn{4}{|c|}{ Percent relative viability ${ }^{a}$ genotype, and the number of progeny $(n)$ recovered from each cross } \\
\hline & & $\begin{array}{l}\text { snf/Sxl, sis- } a \\
\text { females }\end{array}$ & $\begin{array}{c}\text { Sxl, sis-a/FM7 } \\
\text { females }\end{array}$ & $\begin{array}{c}\text { nonbalancer } \\
\text { males }\{n \mid\end{array}$ & $\begin{array}{l}\text { control } \\
\text { males }(n)\end{array}$ \\
\hline & & & & $s n f^{1621} / Y$ & \\
\hline A & $s n f^{1621} / F M 7$ & $\begin{array}{l}1.3 \\
|3|\end{array}$ & $\begin{array}{c}19 \\
(44)\end{array}$ & $\begin{array}{c}106 \\
\{244\} \\
s n f^{I A 2} / Y\end{array}$ & $\begin{array}{c}F M 7 / Y \\
(230)\end{array}$ \\
\hline B & $s n f^{I A 2} / F M 7$ & $\begin{array}{c}261 \\
(397)\end{array}$ & $\begin{array}{c}230 \\
(349)\end{array}$ & $\begin{array}{c}259 \\
(394)\end{array}$ & $\begin{array}{c}F M 7 / Y \\
(152)\end{array}$ \\
\hline $\mathrm{C}$ & $s n f^{I A 2} s n f^{I A 2}$ & $\begin{array}{r}55 \\
(327)\end{array}$ & - & - & $\begin{array}{c}\operatorname{snf}^{J A 2} / Y \\
(595)\end{array}$ \\
\hline $\mathrm{D}$ & $s n f^{T 210} / F M 7$ & $\begin{array}{c}122 \\
(276)\end{array}$ & $\begin{array}{c}131 \\
(297)\end{array}$ & $\begin{array}{c}s n f^{/ 210} \\
(0) \\
d h d^{P 8} / Y\end{array}$ & $\begin{array}{c}F M 7 / Y \\
(227)\end{array}$ \\
\hline $\begin{array}{l}\text { E } \\
\text { snf } \\
\end{array}$ & $d h d^{P 8} / F M 7$ & $\begin{array}{l}248 \\
(201)\end{array}$ & $\begin{array}{c}232 \\
(188)\end{array}$ & $\begin{array}{c}184 \\
(149)\end{array}$ & $\begin{array}{c}F M 7 / Y \\
(81)\end{array}$ \\
\hline
\end{tabular}

The lethal synergistic interaction between snf and $S x l$ is enhanced by the addition of a mutation at another sex determination locus, sisterless-a (sis-a) as described in Salz (1992).

${ }^{a}$ Relative viability is defined as the number $(n)$ of experimental animals relative to the number of control males recovered from each cross. To facilitate comparisons of relative viability between the different crosses, balancer males are the most appropriate control males. However, because these males are not as viable as nonbalancer males our estimates of viability are overestimates.

${ }^{\mathrm{b}} \mathrm{cm} \mathrm{Sx} l^{f 1} c t$ sis-a/Y males were crossed to the following females: $(\mathrm{A}) w$ snf ${ }^{1621} c t / F M 7 c_{;}(\mathrm{B}) w$ snf $f^{I A 2} / F M 7 c ;(\mathrm{C}) w s n f^{I A 2} / w s n f^{I A 2} ; P\left(w^{+}\right.$, $d h d^{+} \mid / P\left(w^{+}, d h d^{+}\right) ;(D) w s n f / 210 / F M 7 c$; (E) w $d h d^{P 8} / F M 7 c$.

U1A and U2B". These two proteins, although very similar, bind different target RNAs (for review, see Kenan et al. 1991). U1A binds the U1 small nuclear RNA (snRNA) and is incorporated into the Ul snRNP complex, whereas $\mathrm{U}_{2} \mathrm{~B}^{\prime \prime}$ (in conjunction with $\mathrm{U}_{2} \mathrm{~A}^{\prime}$ ) binds the U2 snRNA and is incorporated into the U2 snRNP complex. In many respects, SNF resembles U2B" more closely than U1A. Not only does SNF have a similar overall structure and molecular weight to U2B" but it also contains a 5-amino-acid motif within the amino-terminal RRM domain (marked 5-MER in Fig. 4B) that is identical to that found in $\mathrm{U}^{2} \mathrm{~B}^{\prime \prime}$. In the human protein, this pentamer region has been shown to be necessary for the U1A protein to discriminate between $\mathrm{U} 1$ and U2 RNA (Scherly et al. 1990a,b; Bentley and Keene 1991). Functional studies, on the other hand, demonstrate that SNF is a Ul snRNP protein. An epitope-tagged SNF protein immunoprecipitates from both Drosophila and human cell extracts, U1 snRNA but not U2 snRNA (Harper et al. 1992). Moreover, R. Mancebo and S. Mount have recently determined that the SNF protein is present in purified Drosophila U1 snRNP complexes (pers. comm.). Clearly, snf encodes a U1 snRNP protein. Whether SNF is the only U1A-like protein in Drosophila remains to be determined.

Role of snf in establishing the female-specific splicing pattern of Sxl

Although the fact that a snf null allele is a non-sex-specific lethal establishes that snf is required for developmental processes unrelated to sex determination, its role in regulating $S x l$ can provide us with valuable insights into its biochemical function. As illustrated in Figure 7, the female-specific SXL protein promotes exon skipping of its own pre-mRNA by binding directly to intron sequences surrounding the male-specific exon, thereby preventing the general splicing machinery from recognizing the male-specific $5^{\prime}$ splice site (Sakamoto et al. 1992; Horabin and Schedl 1993a,b|. Because it is also required to establish the female-specific splice site choice, snf is likely to function in conjunction with $S x l$ to bias the general splicing machinery against the recognition of the male $5^{\prime}$ splice site. These studies suggest that as a component of a Ul snRNP, the SNF protein modulates $5^{\prime}$ splice site recognition. Because U1 snRNPs function early in the splicing pathway, many studies have already implied that differential binding of the U1 snRNP to the $5^{\prime}$ splice site plays a role in the regulation of splice site choice (Rosbash and Séraphin 1991; Hoffman and Grabowski 1992; Siebel et al. 1992; Eperon et al. 1993; Nandabalan et al. 1993). Our studies, however, provide the first demonstration in a multicellular organism that mutations in a U1 snRNP protein alter splicing in vivo.

As a generic component of the U1 snRNP, SNF might be required for the recognition of all $5^{\prime}$ splice sites. Our genetic data are certainly consistent with such a conclusion: The snf null phenotype is a non-sex-specific lethal. Given this scenario, how do we explain the observation that the viable loss-of-function and gain-of-function mutations appear to affect the regulation of $S x l$ preferentially? In the mammalian system, relative levels of splicing factors have been shown to interact in a concentration-dependent manner to influence splice site selection (Ge and Manley 1990; Krainer et al. 1990; Mayeda and 

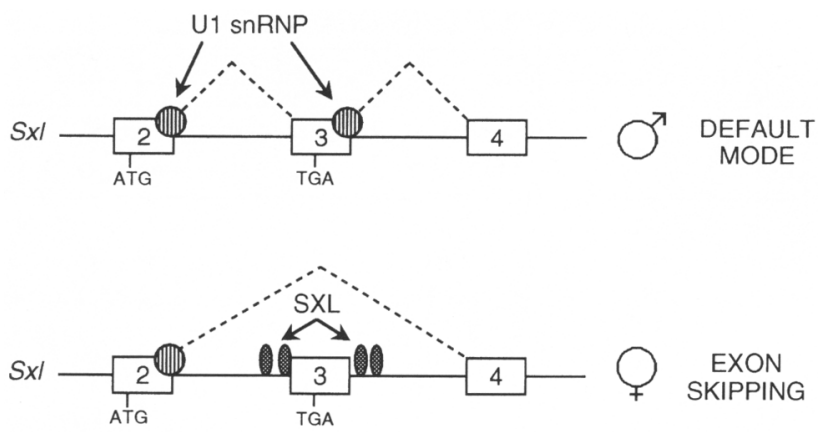

Figure 7. Model of the autoregulatory splicing regulation of the $S x l$ pre-mRNA. Genetic and molecular studies from several laboratories have suggested a detailed model for the sex-specific splicing regulation of the $S x l$ pre-mRNA (see text for references). The regulation of $S x l$ expression can be divided into a two-step process. Initially, female-specific expression is regulated at the level of transcription (not shown). After cellular blastoderm, there is a switch in promoters from the early female-specific promoter to a non-sex-specific promoter. The resulting pre-mRNAs are differentially spliced in males and females. In females, the presence of the SXL protein promotes skipping of the male-specific exon (exon 3), resulting in the production of protein. SXL promotes its own pre-mRNA splicing by binding to poly $(U)$ tracks in the introns surrounding the male-specific exon, thus preventing the general splicing machinery from recognizing the male-specific 5 ' splice site and forcing exon 2 to be joined to exon 4 . In males, on the other hand, there is no SXL protein present; therefore, the $5^{\prime}$ malespecific splice site is recognized and exon 3 is retained. Boxes represent exons; broken lines represent the splicing events.

Krainer 1992; Eperon et al. 1993; Mayeda et al. 1993). Thus, one possibility is that the simultaneous reduction of both snf and $S \times l$ activity affects 5 ' splice site choice, in this case favoring selection of the male-specific $5^{\prime}$ splice site. For instance, although $s n f^{I A 2}$ is a weak loss-of-function mutation, it nonetheless displays a recessive lethal synergistic interaction with Sxl. Similarly, the dominant-negative mutation $s n f^{1621}$ displays a dominant lethal synergistic interaction with $S x 1$. Although there are a number of ways the $\mathrm{SNF}^{1621}$ protein could interfere with the process in which it normally participates, the nature of the snf ${ }^{1621}$ missense mutation suggests that the $\mathrm{SNF}^{1621}$ protein has an altered binding affinity for its target RNA. snf $f^{1621}$ is a missense mutation that substitutes a histidine for a conserved arginine in its aminoterminal RRM domain. In vitro studies have shown that mutation of this conserved arginine can either lower or completely abolish the binding affinity of human U1A for its target RNA (Nagai et al. 1990; Jessen et al. 1991).

A similar argument based on stoichiometry can also explain the sensitivity of the germ line to reductions of snf gene function. snf mutations disrupt $S x l$ regulation in the germ line without the simultaneous reduction of $S x l$ function-a requirement in the soma to see a mutant effect. For example, both $s n f^{1621}$ homozygous females and $s n f^{I A 2} / s n f^{T 210}$ females are sterile irrespective of the genetic background. In the germ line, unlike the soma, the SXL protein is predominately cytoplasmic (Bopp et al. 1991, 1993). Thus, in the germ line, it would appear that only a limited amount of SXL protein is transported to the nucleus where it functions and, therefore, it is always rate limiting (Bopp et al. 1993). Consequently, even small reductions in the level of SNF protein would cause an imbalance in the germ line. In the soma, on the other hand, all of the SXL protein is nuclear localized, suggesting that it is not rate-limiting (Bopp et al. 1991).

Even as a component of a U1 snRNP, SNF might not be required for all splicing events. The fact that snf has greater sequence homology to U2B" than to U1A suggests that the function of snf may not precisely parallel that of the mammalian UlA protein. Perhaps snf is similar to the yeast U1A protein, which is not essential for the recognition of most $5^{\prime}$ splice sites (Liao et al. 1993). In yeast, the absence of UlA has no effect on the assembly or function of U1 snRNPs, either in vitro or in vivo. By analogy, snf function would not be required for the function of most U1 snRNPs, but only for regulated splice sites, such as the $S x l$ male $5^{\prime}$ splice site. If correct, this model predicts that a null mutation would not eliminate splicing but would instead only disrupt specific regulated splicing events. This possibility can now be tested.

\section{Materials and methods}

\section{Note on nomenclature}

A considerable amount of confusion surrounds the naming of the $s n f$ locus. snf was initially identified in a screen for femalesterile mutations and named $f s(1) 1621$ (Gans et al. 1975). Once identified as a sex determination gene it was renamed sans-fille (snf) (Oliver et al. 1988) and liz (Steinmann-Zwicky 1988). Although we have constantly used the acronym snf, (pronounced sniff), others still identify the locus as $f_{s}(1) 1621$ and liz in the literature. In light of the fact that $s n f$ is an snRNP protein whose null phenotype is a non-sex-specific lethal, none of the names assigned to the snf locus are consistent with its phenotype. We therefore propose to retain the acronym snf and rename the locus splicing necessary factor.

\section{Fly stocks and culture conditions}

$s n f^{1621}$ is described in Lindsley and Zimm (1992) as fs(1)A1621. snf $f^{e 8 H}, D f(1) D E B 4 D, D p(1 ; 2) 4 F R D u p$, are described in Salz (1992), and $d h d^{P 8}$ and the $d h d^{+}$transgene $P\left(w^{+}, d h d^{+}\right)$are described in Salz et al. (1994). The remaining mutations and balancer chromosomes are either described in the text or in Lindsley and Zimm (1992). All crosses were carried out at room temperature, which ranged from $22^{\circ} \mathrm{C}-25^{\circ} \mathrm{C}$, on a standard cornmeal, yeast, molasses, agar medium.

\section{Isolation of P-element-induced snf mutations}

To isolate P-element-induced snf mutations, a $\mathrm{P}[\mathrm{lacW}]$ enhancer trap element (Bier et al. 1989) within the $d h d$ gene was mobilized and screened for mutations that did not complement $s n f^{1621}$. To mobilize the P-element insertion, $w d h d^{P 8} / F M 7 c$ virgins were mated to males containing a source of transposase, $\Delta 2-3$ (Robertson et al. 1988), of genotype $w ; S b \Delta 2-3 / T M 6$. The $\mathrm{F}_{1}$ males ( $w d h d^{P 8} ; S b \Delta 2-3 /+$ ) were mated to $C(1) D X$ y w $f$ 
virgins. It is in the germ line of these $F_{1}$ males that the $P$ element can transpose. Single male progeny of this cross that carried a new insertion event (recognized by darker eye color than $d h d^{P 8}$ males, which have light yellow eyes) were crossed to $D f(1) D E B 4 D / F M 7 c$ virgins. Fertility tests of the females with the deficiency from each vial were scored for an eggless femalesterile phenotype. One event, PR110, had this phenotype and was found not to complement snf ${ }^{1621}$

Derivatives of $s n f^{P R 110}$ were isolated as follows: $s n f^{J A 2}$ was isolated in a similar screen as described above except that it was selected for the loss of the P-element insertion as judged by the loss of the $\mathrm{w}^{+}$eye color marker. $s n f^{\prime 210}$ was isolated in a screen that allowed the recovery of lethals. The P element in $s n f^{P R 110}$ was mobilized by crossing $w s n f^{P R 110} / F M 7 c$ virgins to $w ; D r /$ TMS, $\Delta 2-3$ males. The $\mathrm{F}_{1}$ males of genotype, $w$ snf ${ }^{P R 110} ;+1$ TMS, $42-3$ were mated to $y$ w $D f(1)$ ovo $G 6 / F M 7 c$ virgins. $D f(1)$ ovoG6 is an $\mathrm{X}$ chromosome deficiency which does not uncover the snf locus (Oliver et al. 1987). Females of the genotype $w s n f^{P R 110} /$ y $w D f(1)$ ovoG6 in which the P element had remobilized (recognized because the females have white eyes) were individually mated to $F M 7 c$ males and stocks established in the next generation. Males from 335 derivative lines were viable and were therefore screened by PCR for the loss of the first snf exon (P2-P3 amplification product; Fig. 1) without the concomitant loss of the second dhd exon $\{\mathrm{P} 6-\mathrm{P}\rangle$ amplification product; Fig. 1). None of these lines were deleted for the snf gene. Twelve lines contained homozygous lethal derivatives and therefore could not be analyzed by PCR. Consequently, the breakpoints were characterized by genomic Southern blots. One line, $s n f^{2210}$ was identified as a small deletion that only extended through the first exon of the snf gene.

\section{Molecular analysis}

Unless otherwise noted, standard molecular techniques followed the procedures described in Ausubel et al. (1987). Five cDNAs corresponding to snf were obtained by screening a Drosophila head cDNA library in $\lambda$ gt 11 (Itoh et al. 1986) using either a $\sim 2.5-\mathrm{kb}$ BamHI-KpnI or a $\sim 2.8-\mathrm{kb}$ KpnI-EcoRI genomic fragment as probes (Fig. 1). One cDNA clone, $\lambda K E-14$, was characterized further and found to contain a 788-bp insert that hybridized exclusively to the altered transcript in $\operatorname{sn} f^{P R 110}$ (Fig. 2). This cDNA was then subcloned into pBluescript (Stratagene) for sequence analysis. Unidirectional deletions of $\mathrm{pBS} / \mathrm{KE}-14$ were made using exonuclease III and mung bean nuclease (New England Biolabs) as described (Henikoff 1984). These inserts were sequenced by the dideoxy chain termination method (Sanger et al. 1977) using Sequenase v2.0 (U.S. Biochemical). The genomic subclones, $2.5-\mathrm{kb}$ BamHI-KpnI and 2.8-kb KpnIEcoRI were also sequenced in a similar manner. Data base searches and alignments were generated by the BLAST programs at NCBI using the BLAST network service (Altschul et al. 1990).

RNA from adult flies was isolated as described in Chomczynski and Sacchi (1987). Northern transfers and RNase T2 protection assays were carried out as described previously (Flickinger et al. 1992).

Sequencing of the mutant alleles was carried out by direct cycle sequencing of gel-purified PCR-amplified genomic DNA fragments with the CircumVent kit according to the manufacturer's directions (New England Biolabs). In short, $1 \mu \mathrm{g}$ of genomic DNA from wild-type or mutant $s n f$ alleles was amplified in a MJ Research PCT-100 thermocycler using $0.25 \mu \mathrm{M}$ of each primer, $0.2 \mathrm{~mm}$ each dNTP (Promega), 2.5 units of Taq DNA polymerase (Boehringer Mannheim) in $100 \mu \mathrm{l}$ of a standard buffer containing $3 \mathrm{mM} \mathrm{MgCl}$ (Ausubel et al. 1987). The geno- mic DNA from snf ${ }^{1621}$ homozygotes and its parent chromosome were PCR amplified with the P2-P4 primer pair, whereas DNA from $s n f^{7210}$ heterozygotes was amplified using the P2-P7 and P1-P5 primer pairs, respectively (Fig. 1). Forty cycles of the following parameters were used: $30 \mathrm{sec}$ at $94^{\circ} \mathrm{C}, 45 \mathrm{sec}$ at $49^{\circ} \mathrm{C}$, $90 \mathrm{sec}$ at $72^{\circ} \mathrm{C}$, followed by a final 5 -min extension step at $72^{\circ} \mathrm{C}$. The following primers were used: $11,5^{\prime}$-CGTCCACCAAGCCAATGATA-3'; P2, 5'-CTCAACAATACAGAGCAAAT- ${ }^{\prime}$; P3, 5'-GAATCGGATTTGGAGTAG-3'; P4, 5' -AGATCTACACAATAACAATAAA-3'; P5, 5'-GATTGCTGCTTACGCCTT3'; P6, 5'-GTTCGTTTATGTATTCGA-3'; and P7, 5'-AATTGCTTCTTAGTGCCT- 3 '.

\section{Protein analysis}

Immunoblot analysis. Adult flies, embryos, and larvae were collected and frozen on dry ice and then homogenized in $\sim 150$ $\mu 1$ of $2 \times$ SDS loading buffer. Samples were boiled for $\sim 5 \mathrm{~min}$ and then centrifuged for $1 \mathrm{~min}$ at $4000 \mathrm{~g}$ to pellet the debris. Samples $(4-30 \mu l)$ were loaded on a $12.5 \%$ SDS-polyacrylamide gel and electrophoresed. Proteins were electotransferred to a PVDF membrane (Tropix) as described (Towbin et al. 1979). The membrane was blocked and then incubated with a 1:10 dilution of culture supernatant containing mAB 4G3 (Habets et al. 1989). The primary antibody was visualized using chemiluminescence with the Western-Light kit according to the manufacturer's directions (Tropix). In the immunoblots shown in Figure 5, the only antigen detected by $\mathrm{mAb} 4 \mathrm{G} 3$ is a $28-\mathrm{kD}$ protein. However, we and others have observed that a larger cross-reacting protein is sometimes detected by this antibody in both Drosophila and HeLa cell extracts (Amero et al. 1992; Tazi et al. 1993; T. Flickinger, unpubl.). Because the larger protein is similar in size to U1A and is detected in purified U1 snRNPs, it was identified as U1A (Amero et al. 1992; Tazi et al. 1993). Interestingly, we do not detect this $37-\mathrm{kD}$ protein in extracts from either $s n f^{I A 2}$ or $s n f^{P R 110}$ animals under conditions where we do detect it in extracts from wild-type animals. Although the origin of this cross-reacting protein has yet to be determined, its absence in snf mutant extracts suggests the possibility that it is encoded by the snf gene. However, because we have no evidence of any alternative splicing within the snf gene, it is more likely that the expression of this $37-\mathrm{kD}$ antigen represents a protein complex containing the SNF protein.

Immunolocalization in whole mounts The fixation and antibody staining to embryos and salivary glands were performed as described in Salz et al. (1994). The mAb 4G3 was diluted 1:10, stained with a biotinylated goat anti-mouse secondary antibody (Chemicon), diluted 1:5000 and visualized with the Vectastain $\mathrm{ABC}$ elite HRP signal detection system according to the manufacturer's instructions.

\section{Acknowledgments}

We thank R. Mancebo and S. Mount for communicating unpublished results and M. Samuels, J. Horabin, and D. Bopp for suggesting that $\mathrm{mAb} 4 \mathrm{G} 3 \mathrm{might}$ recognize the SNF protein. We also thank A. Beyer and W. Venrooij for $m A b 4 G 3$ and C. Cronmiller, P. Hunt, H. Willard, and members of the Salz laboratory for their critical reading of the manuscript. We are grateful to Nancy Hahn and Alex Pellicena-Palle for their excellent technical assistance. This work was supported by a grant from the National Science Foundation (H.K.S.), a Young Investigators Award from the Mathers Charitable Foundation (H.K.S.), the Markey Foundation (T.W.F.), and the National Research Service Awards HD07104 (T.W.F.). 
The publication costs of this article were defrayed in part by payment of page charges. This article must therefore be hereby marked "advertisement" in accordance with 18 USC section 1734 solely to indicate this fact.

\section{References}

Albrecht, E.B. and H.K. Salz. 1993. The Drosophila sex determination gene snf is utilized to establish the female-specific splicing pattern of Sex-lethal. Genetics 134: 801-807.

Altschul, S.F., W. Gish, W. Miller, E.W. Myers, and D.J. Lipman. 1990. Basic local alignment search tool. J. Mol. Biol. 215: 403-410.

Amero, S.A., G. Raychaudhuri, C.L. Cass, W.J. van Venrooij, W.J. Habets, A.R. Krainer, and A.L. Beyer. 1992. Independent deposition of heterogeneous nuclear ribonucleoproteins and small nuclear ribonucleoprotein particles at sites of transcription. Proc. Natl. Acad. Sci. 89: 8409-8413.

Ausubel, F.M., R. Brent, R.E. Kingston, D.D. Moore, J.G. Siedman, J.A. Smith, and J. Struhl, eds. 1987. Current protocols in molecular biology. Greene Publishing/Wiley-Interscience, New York.

Bell, L.R., E.M. Maine, P. Schedl, and T.W. Cline. 1988. Sexlethal, a Drosophila sex determination switch gene, exhibits sex-specific RNA splicing and sequence similarity to RNA binding proteins. Cell 55: 1037-1046.

Bell, L.R., J.I. Horabin, P. Schedl, and T.W. Cline. 1991. Positive autoregulation of Sex-lethal by alternative splicing maintains the female determined state in Drosophila. Cell 65: 229-239.

Belote, J.M. 1992. Sex determination in Drosophila melanogaster: From the X:A ratio to doublesex. Sem. Dev. Biol. 3: 319-330.

Bentley, R.C. and J.D. Keene. 1991. Recognition of U1 and U2 small nuclear RNAs can be altered by a 5 -amino acid segment in the U2 small nuclear ribonucleoprotein partical (snRNP) B" protein and through interactions with U2 snRNP-

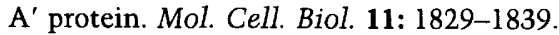

Bier, E., H. Vaessin, S. Shepherd, K. Lee, K. McCall, S. Barbel, L. Ackerman, R. Carretto, T. Uemura, E. Grell, L. Jan, and Y. Jan. 1989. Searching for pattern and mutation in the Drosophila genome with a P-lacZ vector. Genes \& Dev. 3: 12731287.

Bopp, D., L.R. Bell, T.W. Cline, and P. Schedl. 1991. Developmental distribution of female-specific Sex-lethal proteins in Drosophila melanogaster. Genes \& Dev. 5: 403-415.

Bopp, D., J.I. Horabin, R.A. Lersch, T.W. Cline, and P. Schedl. 1993. Expression of the Sex-lethal gene is controlled at multiple levels during Drosophila oogenesis. Development 118: 797-812.

Burtis, K.C. and M.F. Wolfner. 1992. The view from the bottom: Sex-specific traits and their control in Drosophila. Sem. Dev. Biol. 3: 331-340.

Chomezynski, P. and N. Sacchi. 1987. Single step method of RNA isolation by acid guanidinium thiocyanate-phenolchloroform extraction. Anal. Biochem. 162: 156-159.

Cline, T.W. 1984. Autoregulatory functioning of a Drosophila gene product that establishes and maintains the sexually determined state. Genetics 107: 231-277.

Cronmiller, C. and H.K. Salz. 1994. The feminine mystique: The initiation of sex determination in Drosophila. In Molec ular biology of sex differentiation (ed. S.S. Wachtel), pp. 171203. Academic Press, San Diego, CA.

Eperon, I.C., D.C. Ireland, R.A. Smith, A. Mayeda, and A.R. Krainer. 1993. Pathways for selection of $5^{\prime}$ splice sites by U1 snRNPs and SF2/ASF. EMBO I. 12: 3607-3617.
Flickinger, T.W., N.J. Maihle, and H.-J. Kung. 1992. An alternatively processed mRNA from the avian c-erbB gene encodes a soluble, truncated form of the receptor that can block ligand-dependent transformation. Mol. Cell. Biol. 12: 883893.

Fryberg, E.A., J.W. Mahaffey, B.J. Bond, and N. Davidson. 1983. Transcripts of the six Drosophila actin genes accumulate in a stage- and tissue specific manner. Cell 33: 115-123.

Gans, M., C. Audit, and M. Masson. 1975. Isolation and characterization of sex-linked female-sterile mutants in Drosophila melanogaster. Genetics 81: 683-704.

Ge, H. and J.L. Manley. 1990. A protein factor, ASF, controls cell-specific alternative splicing of SV40 early pre-mRNA in vitro. Cell 62: 25-34.

Gollin, S.M. and R.C. King. 1981. Studies on $f s(1) 1621$, a mutation producing ovarian tumors in Drosophila melanogaster. Dev. Genet. 2: 203-218.

Granadino, B., S. Campuzano, and L. Sánchez. 1990. The Drosophila melanogaster fl(2)d gene is needed for the female-specific splicing of Sex-lethal RNA. EMBO I. 9: 2597-2602.

Granadino, B., A.B. San Juán, and L. Sánchez. 1991. The gene $f l(2) d$ is required for various $S x l$-controlled processes in Drosophila females. Wilhelm Roux's Arch. Dev. Biol. 200: $172-176$

Granadino, B., A.B. San Juán, P. Santamaria, and L. Sánchez. 1992. Evidence of a dual function in $f 1(2) d$, a gene needed for Sex-lethal expression in Drosophila melanogaster. Genetics 130: $597-612$.

Green, M.R. 1991. Biochemical mechanisms of constitutive and regulated pre-mRNA splicing. Annu. Rev. Cell Biol. 7: 559599.

Habets, W.J., P.T.G. Sillekens, M.H. Hoet, J.A. Schalken, A.J.M. Roebroek, J.A.M. Leunissen, W.J.M. van de Ven, and W.J. van Venrooij. 1987. Analysis of a cDNA clone expressing a human autoimmune antigen: Full-length sequence of the U2 small nuclear RNA-associated B" antigen. Proc. Natl. Acad. Sci. 84: 2421-2425.

Habets, W.J., M.H. Hoet, B.A.W. de Jong, A. van der Kemp, and W.J. van Venrooij. 1989. Mapping of B cell epitopes on small nuclear ribonucleoproteins that react with human autoantibodies as well as with experimentally-induced mouse monoclonal antibodies. I. Immunol. 143: 2560-2566.

Harper, D.S., L.D. Fresco, and J.D. Keene. 1992. RNA binding specificity of a Drosophila snRNP protein that shares sequence homology with mammalian U1-A and U2-B' proteins. Nucleic Acids Res. 20: 3645-3650.

Henikoff, S. 1984. Unidirectional digestion with exonuclease III creates targeted breakpoints for DNA sequencing. Gene 28: 351-359.

Herskowitz, I. 1987. Functional inactivation of genes by domiant negative mutations. Nature 329: 219-222.

Hoffman, B.E. and P.J. Grabowski. 1992. U1snRNP targets an essential splicing factor, U2AF65, to the $3^{\prime}$ splice site by a network of interactions spanning the exon. Genes \& Dev. 6: 2554-2568.

Horabin, J.I. and P. Schedl. 1993a. Regulated splicing of the Drosophila Sex-lethal male exon involves a blockage mechanism. Mol. Cell. Biol. 13: 1408-1414.

. 1993b. Sex-lethal autoregulation requires multiple cisacting elements upstream and downstream of the male exon and appears to depend largely on controlling the use of the male exon 5' splice site. Mol. Cell. Biol. 13: 7734-7746.

Itoh, N., J.R. Slemmon, D.H. Hawke, R. Williamson, E. Morita, K. Itakura, and P.M. Salvaterra. 1986. Cloning of Drosophila choline acetyltransferase cDNA. Proc. Natl. Acad. Sci. 83: 4081-4085. 
Jessen, T.-H., C. Oubridge, C.H. Teo, C. Pritchard, and K. Nagai. 1991. Identification of molecular contacts between the U1A small nuclear ribonucleoprotein and U1 RNA. EMBO $\%$ 10: $3447-3456$.

Kenan, D.J., C.C. Query, and J.D. Keene. 1991. RNA recognition: Towards identifying determinants of specificity. Trends Biochem. Sci. 16: 214-220.

Keyes, L.N., T.W. Cline, and P. Schedl. 1992. The primary sexdetermination signal of Drosophila acts at the level of transcription. Cell 68: 933-943.

Krainer, A.R., G. Conway, and D. Kozak. 1990. The essential pre-mRNA splicing factor SF2 influences 5 ' splice site selection by activating proximal sites. Cell 62: 35-42.

Liao, X.C., J. Tang, and M. Rosbash. 1993. An enhancer screen identifies a gene that encodes the yeast Ul snRNP A protein: Implications for snRNP protein function in pre-mRNA splicing. Genes \& Dev. 7: 419-428.

Lindsley, D. and G.G. Zimm. 1992. The genome of Drosophila melanogaster. Academic Press, San Diego, CA.

Mayeda, A. and A.R. Krainer. 1992. Regulation of alternative pre-mRNA splicing by hnRNP A1 and splicing factor SF2. Cell 68: 365-375.

Mayeda, A., D.M. Helfman, and A.R. Krainer. 1993. Modulation of exon skipping and inclusion by heterogeneous nuclear ribonucleoprotein $\mathrm{A} 1$ and pre-mRNA splicing factor SF2/ ASF. Mol. Cell. Biol. 13: 2993-3001.

McKeown, M. 1990. Regulation of alternative splicing. In $\mathrm{Ge}$ netic engineering (ed. J.K. Setlow), pp. 139-181. Plenum Press, New York.

McKeown, M. and S.J. Madigan. 1992. Sex determination and differentiation in invertebrates: Drosophila and Caenorhabditis elegans. Curr. Opin. Cell Biol. 4: 948-954.

Muller, H.J. 1932. Further studies on the nature and causes of gene mutations. Proc. 6th Int. Congr. Genet. 1: 213-252.

Nagai, K., C. Oubridge, T.H. Jessen, J. Li, and P.R. Evans. 1990. Crystal structure of the RNA-binding domain of the U1 small nuclear ribonucleoprotein A. Nature 348: 515-520.

Nandabalan, K., L. Price, and G.S. Roeder. 1993. Mutations in U1 snRNA bypass the requirement for a cell type-specific RNA splicing factor. Cell 73: 407-415.

Oliver, B., N. Perrimon, and A.P. Mahowald. 1987. The ovo locus is required for sex-specific germ line maintenance in Drosophila. Genes \& Dev. 1: 913-923.

Oliver, B., N. Perrimon, and A.P. Mahowald. 1988. Genetic evidence that the sans fille locus is involved in Drosophila sex determination. Genetics 120: 159-171.

Oliver, B., Y.-J. Kim, and B.S. Baker. 1993. Sex-lethal, master and slave: A hierarchy of germline sex determination in Drosophila. Development 119: 897-908.

Robertson, H.M., C.R. Preston, R.W. Phillis, D.M. JohnsonSchulitz, W.K. Benz, and W.R. Engels. 1988. A stable genomic source of P element transposase in Drosophila melanogaster. Genetics 118: 461-470.

Rosbash, M. and B. Séraphin. 1991. Who's on first? The U1 snRNP-5' splice site interaction and splicing. Trends Biochem. Sci. 16: 187-190.

Sakamoto, H., K. Inoue, I. Higuchi, Y. Ono, and Y. Shimura. 1992. Control of Drosophila Sex-lethal pre-mRNA splicing by its own female-specific product. Nucleic Acids Res. 20: $5533-5540$.

Salz, H.K. 1992. The genetic analysis of snf: A Drosophila sex determination gene required for activation of Sex-lethal in both the germline and the soma. Genetics 130: 547-554.

Salz, H.K., E.M. Maine, L.N. Keyes, M.E. Samuels, T.W. Cline, and P. Schedl. 1989. The Drosophila female-specific sex determination gene, Sex-lethal, has stage-, tissue-, and sex-spe- cific RNAs suggesting multiple modes of regulation. Genes \& Dev. 3: 708-719.

Salz, H.K., T.W. Flickinger, E. Mittendorf, A. Pellicena-Palle, J.P. Petschek, and E.B. Albrecht. 1994. The Drosophila maternal effect locus deadhead encodes a thioredoxin homolog required for female meiosis and early embryonic development. Genetics 136: 1075-1086.

Samuels, M.E., P. Schedl, and T.W. Cline. 1991. The complex set of late transcripts from the Drosophila sex determination gene Sex-lethal encodes multiple related polypeptides. Mol. Cell. Biol. 11: 3584-3602.

Sanger, F., S. Nicklen, and A.R. Coulson. 1977. DNA sequencing with chain-terminating inhibitors. Proc. Natl. Acad. Sci. 74: 5463-5467.

Scherly, D., W. Boelens, N.A. Dathan, W.J. van Rooij, and I.W. Mattaj. 1990a. Major determinants of the specificity of interaction between small nuclear ribonucleoproteins U1A and $\mathrm{U}_{2} \mathrm{~B}^{\prime \prime}$ and their cognate RNAs. Nature 345: 502-506.

Scherly, D., N.A. Dathan, W. Boelens, W.J. van Venrooij, and I.W. Mattaj. 1990b. The U2B" RNP motif as a site of protein-protein interaction. EMBO J. 9: 3675-3681.

Scherly, D., C. Kambach, W. Boelens, W.J. van Venrooij, and I.W. Mattaj. 1991. Conserved amino acid residues within and outside of the amino-terminal ribonucleoprotein motif of U1A small nuclear ribonucleoprotein involved in U1 RNA binding. J. Mol. Biol. 219: 577-584.

Siebel, C.W., L.D. Fresco, and D.C. Rio. 1992. The mechanism of somatic inhibition of Drosophila P-element pre-mRNA splicing; multiprotein complexes at an exon pseudo-5' splice site control U1 snRNP binding. Genes \&) Dev. 6: 1386-1401.

Sillekens, P.T.G., W.J. Habets, R.P. Beijer, and W.J. Venrooij. 1987. cDNA cloning of the human U1 snRNA-associated A protein: Extensive homology between U1 and U2 snRNP specific proteins. EMBO J. 6: 3841-3848.

Simpson, G.G., P. Vaux, G. Clark, R. Waugh, J.D. Beggs, and J.W.S. Brown. 1991. Evolutionary conservation of the spliceosomal protein, U2B". Nucleic Acids Res. 19: 5213-5217.

Steinmann-Zwicky, M. 1988. Sex determination in Drosophila: The X-chromosomal gene $l i z$ is required for $S x l$ activity. EMBO I. 7: 3889-3898.

- 1992. Sex determination of Drosophila germ cells. Sem. Dev. Biol. 3: 341-347.

Tazi, J., U. Kornstadt, F. Rossi, P. Jeanteur, G. Cathala, C. Brunel, and R. Luhrmann. 1993. Thiophosphorylation of U170K protein inhibits pre-mRNA splicing. Nature 363: 283286.

Towbin, H., T. Staehelin, and J. Gordon. 1979. Electrophoretic transfer of proteins from polyacrylamide gels to nitrocellulose sheets: Procedure and some applications. Proc. Natl. Acad. Sci. 76: 4350-4354.

Tower, J., G.H. Karpen, N. Craig, and A.C. Spradling. 1993. Preferential transposition of Drosophila P elements to nearby chromosomal sites. Genetics 133: 347-359.

Tsai, D.E., D.S. Harper, and J.D. Keene. 1991. U1snRNP-A protein selects a ten nucleotide consensus sequence from a degenerate RNA pool presented in various structural contexts. Nucleic Acids Res.19: 4931-4936. 


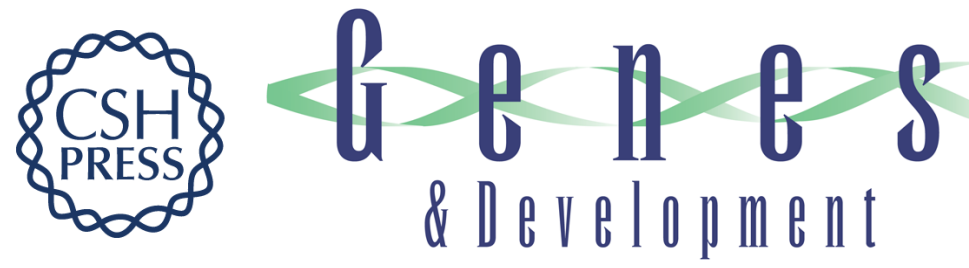

\section{The Drosophila sex determination gene snf encodes a nuclear protein with sequence and functional similarity to the mammalian U1A snRNP protein.}

T W Flickinger and $\mathrm{H} \mathrm{K} \mathrm{Salz}$

Genes Dev. 1994, 8:

Access the most recent version at doi:10.1101/gad.8.8.914

References This article cites 66 articles, 30 of which can be accessed free at: http://genesdev.cshlp.org/content/8/8/914.full.html\#ref-list-1

License

Email Alerting Receive free email alerts when new articles cite this article - sign up in the box at the top Service right corner of the article or click here.

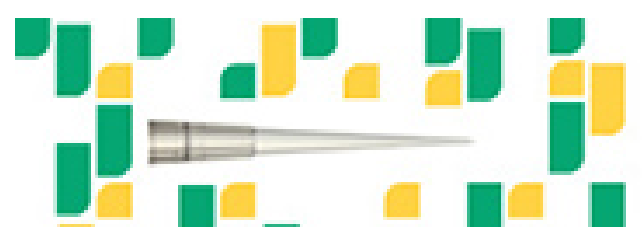

Focused on your science. 